\title{
Strategi Pengembangan Industri Gula Merah Lontar Sebagai Resource Based Industry di Kabupaten Jeneponto
}

\author{
Strategy for The Development of Lontar Brown Sugar Industry as A Resource Based \\ Industry in Jeneponto District
}

\author{
Syahmidarni Al Islamiyah \\ Program Studi Teknologi Hasil Pertanian Politeknik Gorontalo, Jl. Muchlis Rahim, Desa Panggulo Barat, \\ Kecamatan Botupingge, Kabupaten Bone Bolango, Provinsi Gorontalo
}

*Penulis korespondensi: Syahmidarni Al Islamiyah, e-mail: islamiyah01@ poligon.ac.id

Tanggal submisi: 10 September 2020; Tanggal penerimaan: 19 Februari 2021

\begin{abstract}
The lontar sugar industry in Jeneponto Regency is one of the local industries managed by societies on a domestic scale. The complexity of the problems has slowed down the growth of the industry. Therefore, it is important to create a development strategy with the concept of agro-industry or resource-based industry. The purpose of this research was to analyze and strategize the concept. Data collected in this study was by survey, interview, questionnaire, and literature study. SWOT analysis (Strength, Weakness, Opportunities, and Threats) was applied to develop strategies. The SWOT analysis results obtained a strategy (SO, ST, WO, WT), which consists of 16 alternative strategy formulations., Five strategic formulations were obtained based on the ranking from the highest score: increasing production capacity, entrepreneurship training, forming partnership businesses, forming collaborative business groups, and promoting palm sugar products as superior regional products.
\end{abstract}

Keywords: Brown sugar; Jeneponto; lontar; resource-based industry; strategy

(C) The Authors. Publisher Universitas Pattimura. Open access under CC-BY-SA license.

\begin{abstract}
ABSTRAK
Industri gula merah lontar di Kabupaten Jeneponto adalah salah satu industri lokal yang dikelola oleh masyarakat dengan skala rumah tangga. Kompleksnya masalah yang dihadapi menyebabkan lambatnya perkembangan industri ini. Oleh karena itu, penting untuk membuat strategi pengembangan dengan konsep agroindustri atau resource based industry. Tujuan dari penelitian ini adalah untuk menganalisis dan menyusun strategi. Metode pengumpulan data dengan survey, wawancara, kusioner dan studi pustaka. Analisis data untuk menyusun strategi dengan analisis Strenght, Weakness, Opportunities and Threats (SWOT). Hasil analisis SWOT diperoleh 16 formulasi alternatif strategi. Berdasarkan peringkatan diperoleh lima formulasi strategi berurut dari skor tertinggi yaitu menambah kapasitas produksi, pelatihan kewirausahaan, membentuk usaha kemitraan, membentuk kelompok usaha bersama, dan mempromosikan produk gula lontar sebagai produk unggulan daerah.
\end{abstract}

Kata Kunci: Gula-merah; Jeneponto; lontar; resource based industry; strategi

(C) Penulis. Penerbit Universitas Pattimura. Akses terbuka dengan lisensi CC-BY-SA.

\section{PENDAHULUAN}

Industri kecil gula merah lontar di Kabupaten Jeneponto adalah salah satu industri lokal yang masih tetap bertahan di tengah perkembangan industri. Industri ini dikelola oleh masyarakat skala rumah tangga. Lontar sendiri menjadi ikon daerah yang merupakan tanaman endemik. Pohon ini banyak tumbuh liar di lahan perkebunan masyarakat dan menjadi salah satu sumber mata pencaharian. Pusat sebaran pohon lontar berada di tiga kecamatan yaitu Kecamatan Bangkala, Kecamatan Tamalatea dan Kecamatan Binamu (Islamiyah, 2017). Data Dinas Perkebunan dan Kehutanan Kabupaten Jeneponto tahun 2014 menyebutkan luas areal perkebunan lontar 
mencapai 427,50 Ha dengan produksi gula merah lontar berkisar Rp. 14.442.831 atau mencapai 16,437 ton.

Kompleksitas masalah yang dihadapi menyebabkan lambatnya perkembangan industri ini. Masalah yang masih dihadapi meliputi teknologi pengolahan yang masih sederhana, rendahnya kualitas gula merah, akses pemasaran yang terbatas, masih adanya pembuatan tuak oleh sebagian masyarakat. Meski demikian, industri ini berpotensi untuk dikembangkan sebagaimana yang dinyatakan oleh Islamiyah (2020), bahwa posisi industri ini berada di posisi koordinat positif. Artinya kondisi lingkungan perusahaan didominasi oleh faktor internal yang menandakan situasi industri pengolahan gula merah lontar sangat menguntungkan untuk dikembangkan. Berbagai faktor yang menghambat industri ini sehingga diperlukan strategi dalam pengembangannya (Wongkar et al., 2017).

Konsep pengembangan industri kecil yang bertumpu pada sumber daya alam lokal adalah agroindustri yang bersifat resource based industry yaitu industri yang pengembangannya harus didasarkan pada wilayah potensi sumberdaya, sehingga pemerintah diharapkan membuat peta pengembangan agroindustri. Jika hal ini dilaksanakan maka pengembangan agroindustri tidak hanya sekedar berkembang, tetapi lebih dari itu mampu meningkatkan perekonomian di daerah sekitarnya. Karakteristik agroindustri yang bersifat resources based industry untuk dijadikan sebagai sektor yang diharapkan mendongkrak perekonomian pedesaan, maka arah strategi pengembangannya harus didasarkan pada pendekatan wilayah potensi sumberdaya dengan tetap berpijak pada konsep keunggulan komparatif dinamis, peran serta pemerintah untuk dapat mengarahkan keunggulan komparatif dalam jangka panjang. Oleh karena itu, pengembangan industri gula merah lontar dengan konsep resource-based industry sangat sesuai dengan memperhatikan faktor-faktor yang mempengaruhi industri tersebut baik internal maupun eksternal. Dengan adanya industri dengan konsep resource-based industry diharapkan menyerap banyak tenaga kerja (Hasanah et al., 2015), peningkatan nilai tambah (Arianti dan Waluyati, 2019), menyuplai kebutuhan gula merah di Indonesia dan Sulawesi khususnya.

Penelitian tentang pengembangan industri gula merah dengan menggunakan Strenght, Weakness, Opportunities and Threats (SWOT) sudah ada, tetapi penelitian yang objek penelitiannya tentang industri gula merah lontar di
Kabupaten Jeneponto belum ada. Selain itu, tidak melakukan pemeringkatan formulasi strategi yang diperoleh. Adapun penelitian yang ada kaitannya dengan penelitian ini adalah penelitian tentang potensi lontar yang dilakukan oleh Tambunan (2010) yang menyatakan bahwa lontar merupakan tumbuhan yang serba guna yang berpotensi menghasilkkan produk yang bernilai ekonomi tinggi, seperti etanol, nata dan gula, produk lontar menjadi produk unggulan daerah yang sangat mendukung peningkatan pendapatan petani, penyediaan lapangan kerja, penerimaan daerah dan devisa negara, dan penggalian dan pengembangan potensi produk lontar belum maksimal karena keterbatasan pemasaran, pengetahuan dan teknologi. Gabriel (2013) merumuskan perencanaan strategi pengembangan industri rumah tangga gula kelapa (studi kasus industri tumah tangga gula kelapa di Desa Gledug Kecamatan Sanan Kulon, Kabupaten Blitar). Dengan menguraikan masalah bagaimana alternatif perencanaan strategi yang tepat menggunakan analisis SWOT dan mengetahui prioritas strategi pengembangan usaha IRT gula kelapa di Desa Gledug dengan metode Analytical Network Process (ANP). menyusun strategi pengembangan industri kecil gula dengan metode SWOT (Karmiati, 2016; Maemunah, 2015; Saputra et al., 2012).

Penelitian ini dilakukan untuk menganalisis dan menyusun strategi di dalam sebuah metode analisis strategi yaitu analisis SWOT. Analisis SWOT adalah identifikasi berbagai faktor secara sistematis untuk merumuskan strategi perusahaan. Analisis ini didasarkan pada logika yang dapat memaksimalkan kekuatan (Strengths) dan peluang (Opportunities), namun secara bersamaan dapat meminimalkan kelemahan (Weakness) dan ancaman (Threats) (Siregar et al., 2014). Mengembangkan alternatif strategi digunakan matriks SWOT untuk membantu dalam melakukan penyesuaian antar kekuatan dan peluang (strategi SO), kekuatan dan ancaman (strategi ST), peluang dan kelemahan (strategi WO) serta kelemahan dan ancaman (strategi WT) (Kurniawan dan Haryati, 2017).

\section{METODE}

\section{Metode Penelitian}

Penelitian ini dilaksanakan di Kabupaten Jeneponto, Sulawesi Selatan. Metode penelitian dilakukan secara deskriptif kualitatif. Data dianalisis menggunakan analisis SWOT. Strategi yang 
diperoleh kemudian dilakukan pemeringkatan berdasarkan skor tertinggi sampai terendah.

\section{Prosedur Penelitian}

Penelitian ini terdiri dari tiga tahap yaitu:

1. Pengumpulan data

Tahap pengumpulan data dilakukan melalui survey, wawancara, penyebaran serta pengisian kusioner kepada panelis dan studi pustaka. Panelis terdiri dari pengolah, pemerintah (dinas terkait), peneliti dan akademisi.

2. Analisis data dan penyusunan strategi dengan metode SWOT (Rangkuti, 2005)

Analisis data dan penyusunan strategi dilakukan dengan menggunakan analisis matriks SWOT.

3. Pemeringkatan formulasi strategi

Formulasi strategi yang diperoleh dari hasil analisis SWOT dilakukan pemeringkatan berdasarkan skor tertinggi untuk mendapatkan strategi terbaik.

\section{HASIL DAN PEMBAHASAN}

Industri gula merah lontar yang dikelola oleh masyarakat Jeneponto ini masih berskala kecil sehingga memiliki banyak faktor yang membuat industri ini lambat untuk berkembang. Tambunan (2003) dan Mulyanto (2006) menyatakan bahwa industri sifat yang lebih cenderung suka bergerak sendiri-sendiri dan tidak terorganisir, industri ini memiliki nilai tawar yang rendah dalam pasar bisnis. Meski demikian, industri gula merah lontar ini memiliki potensi internal maupun eksternal yang baik untuk dikembangkan. Sebagaimana penelitian yang dilakukan oleh Islamiyah (2020), bahwa posisi industri ini berada di posisi koordinat positif. Artinya kondisi lingkungan perusahaan didominasi oleh faktor internal yang menandakan situasi industri pengolahan gula merah lontar sangat menguntungkan untuk pengembangan ke depan. Agroindustri ini memiliki peluang pengembangan dalam mendukung swasembada gula nasional (Kusumanto, 2016).

Matriks SWOT (Tabel 1) menunjukkan ada empat formulasi strategi yaitu strategi kekuatan dan peluang (strategi SO atau agresif), strategi kekuatan dan ancaman (strategi ST atau diversifikasi), strategi kelemahan dan peluang (strategi WO atau turn around), serta strategi kelemahan dan ancaman (strategi WT atau defensif). Matriks SWOT terlihat pada Tabel 2.

\section{Strategi SO (Strenghts - Oportunities)}

Pada matriks SWOT diperoleh alternatif strategi SO yaitu:

\section{Menambah Kapasitas Produksi}

Alternatif strategi ini diperoleh dari hasil formulasi antara kekuatan dan peluang ( $\mathrm{S} 1, \mathrm{~S} 2, \mathrm{~S} 3$, S4, S5, O1, O2, O3, O4, O5, O7). Menambah kapasitas produksi dilakukan dengan menggunakan kekuatan internal seperti ketersediaan bahan baku. Bahan baku/bahan mentah merupakan kebutuhan utama yang harus dipenuhi dan selalu tersedia dalam jumlah yang besar untuk kelancaran dan keberlanjutan proses produksi.

Selain itu, faktor lain yang mendukung strategi ini adalah ketersediaan tenaga kerja, lahan, proses pengolahan yang mudah, biaya produksi yang relatif rendah, besarnya peluang pasar, perkembangan teknologi informasi sehingga promosi produk lebih mudah, perluasan jaringan pemasaran, informasi teknologi pengolahan terbaru untuk pengolahan gula merah, ketersediaan kredit usaha rakyat dari berbagai lembaga pembiayaan baik pemerintah maupun swasta serta terbukanya jalan bermitra dengan mereka seperti dengan menambah fasillitas dan peralatan produksi.

Tabel 1. Contoh matriks SWOT

\begin{tabular}{ccc}
\hline Faktor Eksternal & Kekuatan (Strength) & Kelemahan (Weakness) \\
\hline Peluang (Opportunities) & $\begin{array}{c}\text { Strategi S-O (Agresif) } \\
\text { Ciptakan strategi yang mnggunakan } \\
\text { kekuatan untuk memanfaatkan } \\
\text { peluang }\end{array}$ & $\begin{array}{c}\text { Strategi W-O (turn around) } \\
\text { Ciptakan strategi yang mengatasi } \\
\text { kelemahan untuk memanfaatkan } \\
\text { peluang }\end{array}$ \\
$\begin{array}{c}\text { Strategi S-T (defensif) } \\
\text { Menggunakan kekuatan untuk }\end{array}$ & $\begin{array}{c}\text { Strategi W-T (diversifikasi) } \\
\text { mengatasi ancaman }\end{array}$ \\
\hline
\end{tabular}

Sumber: Rangkuti (2005) 
Dengan menambah kapasitas produksi, volume produksi akan bertambah sehingga mampu memanfaatkan peluang pasar dan pemenuhan kebutuhan gula merah baik kebutuhan rumah tangga maupun kebutuhan industri. Berdasarkan data proyeksi dan pemenuhan kebutuhan konsumsi penduduk berdasarkan kelompok bahan pangan nasional tahun 2013-2015 dan badan ketahanan pangan nasional dan BPS terlihat kebutuhan gula merah nasional baru sebagian terpenuhi. Pada tahun 2013, proyeksi kebutuhan gula merah sebesar 260.023,50 ton sedangkan angka pemenuhannya $174.408,50$ ton saja. Tahun 2014 proyeksi kebutuhan mencapai 282.033,20 ton sedangkan pemenuhannya sebesar 168,267,00 ton. Pada tahun 2015 diproyeksikan kebutuhan gula merah mencapai $302.487,80$ ton dengan jumlah penduduk 255.461.700 jiwa. Data ini menunjukkan bahwa besarnya peluang industri ini dikembangkan untuk menjadi bagian dari penyuplai/penyedia kebutuhan gula nasional. Data ini menunjukkan adanya potensi pasar bagi gula merah terutama gula merah lontar di Kabupaten Jeneponto.

\section{Mempromosikan Produk Gula Merah Lontar Sebagai Produk Unggulan Daerah}

Alternatif strategi ini diperoleh dari hasil formulasi antara kekuatan dan peluang (S6, S7, S8, O1, O2, O3, O5, O6). Strategi ini didukung oleh kekuatan produk gula merah lontar sebagai produk industri rumah tangga yang sudah turun temurun, banyaknya kandungan dan manfaat gula merah, fungsinya sebagai pengganti gula pasir, adanya dukungan pemerintah, perkembangan teknologi dan informasi, popularitas gula merah di kalangan masyarakat dan kebutuhan industri minuman dan makanan. Strategi ini sebagai alat untuk menarik perhatian dan minat komsumen terhadap produk juga sebagai pendorong percepatan peningkatan pendapatan ekonomi desa khususnya dan pendapatan daerah umumnya. Produk unggulan memiliki posisi yang strategis untuk dikembangkan di suatu wilayah/daerah. Hal ini sesuai Hidayah (2010) menyatakan bahwa komoditas unggulan adalah komoditas andalan yang memiliki posisi strategis untuk dikembangkan di suatu wilayah. Model pengembangan ini juga sesuai dengan program Produk Unggulan Kawasan Pedesaan (Prukades) dari Kemendes PDTT. Dikutip dari pernyataan menteri Kemendes PDTT Eko Putra Sadjojo mengatakan "Program Prukades bisa mempercepat pertumbuhan ekonomi di desa" (Sartina, 2019). Langkah realisasi strategi ini seperti mengikutkan produk gula merah lontar di pameran-pameran, baik tingkat daerah, provinsi maupun tingkat nasional, mengadakan gerakan cinta produk daerah sendiri, sosialisasi manfaat konsumsi gula merah sebagai subtitusi gula pasir. Upaya ini sebagai pembuka akses pemasaran sehingga mudah diketahui dan dikenal baik di dalam maupun luar daerah. Selain itu, untuk menggeser dan memperbaiki pandangan orang terhadap Jeneponto sebagai penghasil tuak yang terkesan negatif.

\section{Membentuk Usaha Kemitraan}

Alternatif strategi ini diperoleh dari hasil formulasi antara kekuatan dan peluang (S1, S2, S3, O1, O2, O4, O5, O7). Pola usaha kemitraan merupakan proses kerjasama yang saling menguntungkan antara berbagai pihak/aktor yang terlibat dalam pengembangan baik pengolah, pemerintah, swasta dan lembaga keuangan sebagai mitra. Menurut Maarif dan Syam (2008), pola usaha ini tepat dalam pengembangan agroindustri dengan memanfaatkan potensi pasar, dukungan pemerintah, bantuan modal, kesempatan bermitra dengan pengusaha besar/industri makanan dan minuman, hubungan ekonomi yang saling menguntungkan dengan lembaga pemberi pinjaman (kredit). Kemitraan yang saling bersinergi akan meningkatkan produktivitas karena masing-masing pihak berkonsentrasi pada kegiatan yang menjadi keahliannya untuk mencapai tujuan yang sama. Secara teoritis pola usaha agroindustri dapat dikembangkan melalui Pola Mandiri, Mitra Usaha dan Koperasi.

\section{Strategi ST (Strenghts - Threats)}

Pada matriks SWOT diperoleh alternatif strategi ST yaitu :

\section{Pelatihan Kewirausahaan}

Alternatif strategi ini diperoleh dari hasil formulasi antara kekuatan dan ancaman (S1, S2, S3, S4, S5, S6, S7, T1, T2, T4). Pelatihan kewirausahaan bertujuan untuk perbaikan pola pikir pengolah, masyarakat terutama kalangan anak muda untuk melestarikan usaha yang telah menjadi usaha warisan. Selain itu, untuk membuka wawasan para pengolah dan masyarakat akan besarnya nilai tambah dan manfaat yang didapatkan dari mengolah gula merah dibanding membuat tuak, memberikan pengetahuan dan informasi mengenai keterbaruan teknologi, cara memproduksi gula merah yang berkualitas, jenis kemasan yang cocok dan menarik, informasi pasar, perbaikan sistem usaha agar lebih terkonsep dan terarah dan sebagainya. Pelatihan ini disertai 
pembinaan dan pendampingan secara intensif dan berkesinambungan.

\section{Melakukan Inovasi Produk}

Alternatif strategi ini diperoleh dari hasil formulasi antara kekuatan dan ancaman (S6, S7, T5). Kualitas gula merah lontar hasil olahan masyarakat terbilang masih rendah sehingga kurang mampu bersaing di pasar. Strategi inovasi produk perlu dilakukan karena banyaknya produk pesaing gula merah beredar di pasaran dengan kualitas yang lebih baik. Beraneka jenis pilihan produk gula merah yang ada di pasaran memberikan banyak pilihan kepada para konsumen dan akan mempengaruhi peluang pasar bagi produk gula merah lontar. Contoh inovasi produk gula merah yang sedang berkembang saat ini di pasaran adalah gula merah dalam bentuk gula semut (gula bubuk) dan gula merah cair dengan kemasan botol. Kedua inovasi produk ini memiliki kelebihan lebih praktis, ekonomis, dengan kemasan yang lebih menarik dan berdaya saing.

\section{Strategi WO (Weaknesses - Oportunities)}

Hasil analisis matriks SWOT diperoleh alternatif strategi WO yaitu:

\section{Perbaikan Manajemen Usaha}

Alternatif strategi ini diperoleh dari hasil formulasi antara kelemahan dan peluang (W1, W4, W10, W11, O1, O2, O5). Perbaikan manajemen usaha dengan perencanaan dan pengendalian produksi, menerapkan tata cara kerja dan penanganan bahan baku dan produk yang baik, menerapkan sistem penjadwalan produksi dan distribusi produk untuk meminimalisir kerusakan bahan baku dan produk, perbaikan manajerial produksi dan pemasaran. Dengan demikian, usaha lebih terarah dan peluang pengembangan akan terbuka luas.

\section{Menerapkan/Memanfaatkan Pengolahan Tepat Guna}

Teknologi

Alternatif strategi ini diperoleh dari hasil formulasi antara kelemahan dan peluang (W2, W4, O1, O2, O3, O4). Mengatasi kelemahan dengan menerapkan teknologi tepat guna untuk memanfaatkan peluang pasar, perkembangan teknologi informasi, dukungan pemerintah dan ketersediaan kredit usaha kecil. Penggunaan alat dan mesin produksi yang sesuai dengan kondisi dan kebutuhan industri.

\section{Memanfaatkan Kredit Usaha Kecil}

Alternatif strategi ini diperoleh dari hasil formulasi antara kelemahan dan peluang (W2, W3, W4, W7, W8, W9, O2, O4). Kredit usaha kecil yang disediakan baik oleh lembaga keuangan pemerintah melalui koperasi maupun bank milik negara dan swasta dapat dimanfaatkan untuk permodalan pengolah untuk pengembangan usaha ini menjadi lebih baik.

\section{Memperbaiki Kemasan Produk}

Alternatif strategi ini diperoleh dari hasil formulasi antara kelemahan dan peluang (W4, W7, O2, O3, O4, O5). Memperbaiki kemasan produk dengan menggunakan jenis kemasan yang cocok dengan produk, lebih layak dan lebih menarik. Pengolah bisa mengikuti pelatihan-pelatihan yang diadakan oleh instansi terkait, mencari informasi perkembangan jenis dan desain kemasan produk yang tepat untuk produk gula merah melalui media teknologi informasi yang ada, menambah modal untuk perbaikan kemasan dengan menggunakan pinjaman kredit usaha kecil atau bermitra dengan rumah/industri kemasan.

\section{Bermitra dengan Berbagai Pihak}

Alternatif strategi ini diperoleh dari hasil formulasi antara kelemahan dan peluang (W2, W3, W5, W4, W6, W7, W9, O2, O5, O7). Kemitraan merupakan proses kerjasama yang saling menguntungkan antara berbagai pihak/aktor dalam pengembangan industri pengolahan gula merah lontar seperti pengolah, pemerintah, swasta dan lembaga keuangan. Kemitraan yang saling bersinergi ini akan meningkatkan produktivitas karena masing-masing pihak berkonsentrasi pada kegiatan yang menjadi keahliannya untuk mencapai tujuan yang sama. Permasalahan akan terselesaikan karena bisa dibagi sesuai porsi dan keahlian yang dimiliki.

\section{Memperluas Pemasaran Melalui Media Informasi yang Ada}

Alternatif strategi ini diperoleh dari hasil formulasi antara kelemahan dan peluang (W5, O3, O5, O6, O7). Perkembangan teknologi dan informasi yang ada sekarang sangat efektif dan efisien sebagai media promosi dan penjualan produk industri baik itu melalui media cetak mau pun elektronik. Biayanya pun relatif terjangkau dan menjangkau semua lapisan masyarakat dan jaringan yang lebih luas. 
Tabel 3. Peringkat alternatif strategi pengembangan industri gula merah lontar di Kabupaten Jeneponto

\begin{tabular}{clcc}
\hline \multirow{2}{*}{ No } & \multicolumn{1}{c}{ Alternatif Strategi } & $\begin{array}{c}\text { Total } \\
\text { Skor }\end{array}$ & $\begin{array}{c}\text { Peringkat } \\
\text { Alternatif }\end{array}$ \\
\hline 1 & Menambah kapasitas produksi (S1, S2, S3, S4, S5, O1, O2, O3, O4, O5, O7) & 4,776 & $\mathbf{1}$ \\
2 & Mempromosikan produk gula lontar sebagai produk unggulan daerah (S6, S7, S8, & 2,970 & $\mathbf{5}$ \\
& O1, O2, O3, O5, O6) & 4,038 & $\mathbf{3}$ \\
3 & Membentuk usaha kemitraan (S1, S2, S3, O1, O2, O4, O5, O7) & 1,576 & $\mathbf{1 2}$ \\
4 & Perbaikan manajemen usaha (Perencanaan dan pengendalian produksi) (W1, W4, & & \\
& W10, W11, O1, O2, O5) & 1,636 & $\mathbf{1 1}$ \\
5 & Menerapkan/memanfaatkan teknologi pengolahan tepat guna (W2, W4, O1, O2, & & \\
& O3, O4) & 1,304 & $\mathbf{1 5}$ \\
6 & Memanfaatkan kredit usaha kecil (W2, W3, W4, W7, W8, O2, O4 & 1,713 & $\mathbf{9}$ \\
7 & Memperbaiki kemasan produk (W4, W7, O2, O3, O4, O5) & 2,013 & $\mathbf{6}$ \\
8 & Bermitra dengan pihak lain (W2, W3, W5, W4, W6, W7, W9, O2, O5, O7) & 1,698 & $\mathbf{1 0}$ \\
9 & Memperluas pemasaran melalui media informasi yang ada (W5, O3, O5, O6, O7) & 1,355 & $\mathbf{1 3}$ \\
10 & Meningkatkan kualitas SDM (W6, O2, O3, O5) & 0,812 & $\mathbf{1 6}$ \\
11 & Mengurus perizinan usaha yang jelas (W9, O2, O4) & 1,342 & $\mathbf{1 4}$ \\
12 & Menerapkan Good Housekeeping (W1, W4, W8, W10, W11, O3, O5) & 4,362 & $\mathbf{2}$ \\
13 & Pelatihan kewirausahaan (S1, S2, S3, S4, S5, S6, S7, T1, T2, T4) & 1,956 & $\mathbf{7}$ \\
14 & Melakukan inovasi produk (S6, S7, T5) & 3,447 & $\mathbf{4}$ \\
15 & Membentuk kelompok usaha bersama (W1-11, T1, T3, T4, T5) & 1,759 & $\mathbf{8}$ \\
16 & Meningkatkan kualitas dan daya saing produk (W4, W5, W7, W9, W11, T5) & & \\
\hline
\end{tabular}

Sumber: Data Sekunder Penelitian, 2020.

\section{Meningkatkan Sumber Daya Manusia}

Alternatif strategi ini diperoleh dari hasil formulasi antara kelemahan dan peluang (W6, O2, O3, O5). Upaya ini untuk meningkatkan kualitas sumber daya manusia agar lebih terampil, ulet, dan dapat bekerja efektif serta efisien dengan pembinaan dan pendampingan secara intensif. Pembinaan yang tepat dan kontinu akan memperkuat kinerja sehingga memudahkan pencapaian tujuan. Setiap kegiatan harus direncanakan secara terprogram dan terukur.

\section{Mengurus Perizinan Usaha yang Jelas}

Alternatif strategi ini diperoleh dari hasil formulasi antara kelemahan dan peluang (W9, O2, O4, O5). Adanya izin usaha akan mempermudah kegiatan usaha, mempertahankan dan mengembangkan usaha, memperoleh berbagai fasilitas dari pemerintah, misalnya bantuan permodalan dengan memanfaatkan kredit usaha kecil dari lembaga keuangan seperti bank dan koperasi.

\section{Menerapkan Good House Keeping}

Alternatif strategi ini diperoleh dari hasil formulasi antara kelemahan dan peluang (W1, W4, W8, W10, W11, O3, O5). Penerapan goodhouse keeping dilakukan untuk mendukung terciptanya lingkungan pabrik yang nyaman dan aman, terjaganya kebersihan dan sanitasi lingkungan pabrik dan produk, serta kegiatan produksi dapat berjalan lebih efisien.

\section{Strategi WT (Weaknesses - Threaths)}

Hasil analisis SWOT diperoleh formulasi strategi WT yaitu :

\section{Membentuk Kelompok Usaha Bersama}

Alternatif strategi ini diperoleh dari hasil formulasi antara kelemahan dan ancaman (W1-11, T1, T3, T4, T5). Ini dilakukan untuk memperkuat semua kelemahan industri sehingga dapat meng-atasi semua ancaman. Selain itu, dengan membentuk usaha bersama akan meningkatkan skala usaha yang lebih besar.

\section{Meningkatkan Kualitas dan Daya Saing Produk}

Alternatif strategi ini diperoleh dari hasil formulasi antara kelemahan dan ancaman (W4, W5, W7, W9, W11, T5). Strategi ini untuk meminimalisir beberapa kelemahan seperti kualitas yang rendah, pengemasan seadanya, jaringan pemasaran yang terbatas, dan penanganan bahan baku dan produk. Kualitas dan daya saing menjadi atribut produk untuk menarik pasar lebih banyak. Untuk menghasilkan produk yang berkualitas ma-ka perlu memperhatikan sanitasi dan penanganan bahan baku dan produk dari awal sampai ke tangan konsumen. 


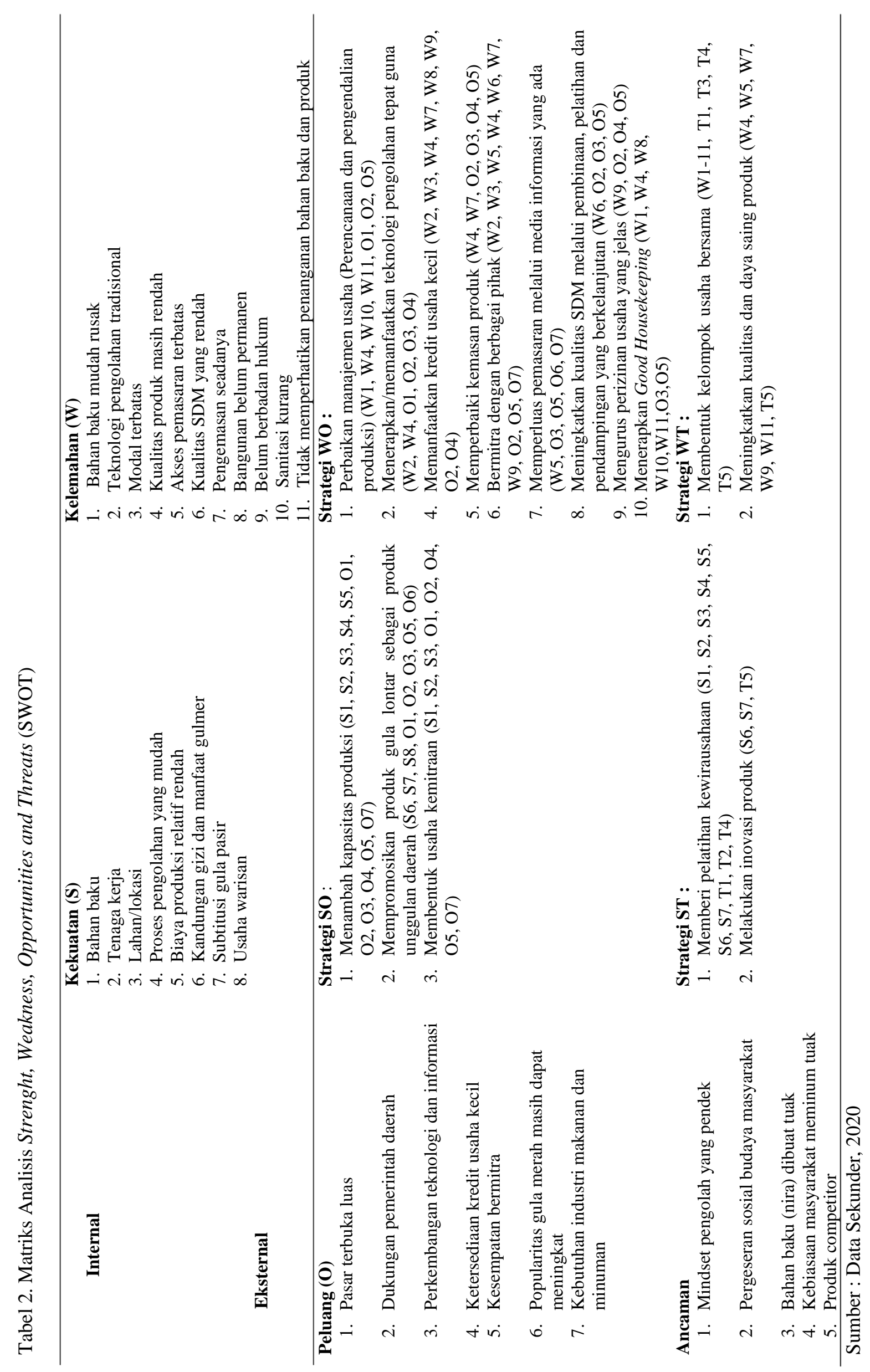




\section{Pemeringkatan Strategi}

Hasil analisis SWOT diperoleh 16 formulasi alternatif strategi pengembangan industri gula merah lontar. Selanjutnya masing-masing diberi skor dengan menjumlah skor formulasi faktor internal dan eksternal yang membentuk alternatif strategi tersebut. Setelah itu diurutkan/diperingkat sesuai besar total skor alternatif strategi.

Tabel 3 menyajikan hasil skor dan peringkat masing-masing alternatif strategi. Berdasarkan peringkatnya, lima alternatif strategi dengan total skor terbesar adalah menambah kapasitas produksi $(4,776)$, pelatihan kewirausahaan $(4,362)$, membentuk usaha kemitraan (4,038), membentuk kelompok usaha bersama $(3,447)$, dan mempromosikan produk gula lontar sebagai produk unggulan daerah $(2,970)$.

\section{KESIMPULAN}

Hasil analisis SWOT diperoleh 16 formulasi alternatif strategi (SO, ST, WO, WT) dan peringkat lima formulasi alternatif strategi teratas yaitu menambah kapasitas produksi, pelatihan kewirausahaan, membentuk usaha kemitraan, membentuk kelompok usaha bersama, dan mempromosikan produk gula lontar sebagai produk unggulan daerah.

\section{DAFTAR PUSTAKA}

Arianti, Y.S., dan L.R. Waluyati. 2019. Analisis nilai tambah dan strategi pengembangan agroindustri gula merah di Kabupaten Madiun. Jurnal Ekonomi Pertanian dan Agribisnis 3: 256-266. DOI: 10.21776/ub. jeoa.2019.003.02.4

Gabriel, A. 2013. Perencanaan Strategi Pengembangan Industri Rumah Tangga Gula Kelapa (Studi Kasus Industri Rumah Tangga Gula Kelapa Desa Gledug, Kecamatan Sanankulon, Kabupaten Blitar). Disertasi. Universitas Brawijaya. URL: http://repository.ib.ac.id/id/eprint/ 149449

Hasanah, U., Masyhuri, dan Djuwari. 2015. Analisis nilai tambah agroindustri sale pisang di Kabupaten Kebumen. Ilmu Pertanian 18: 141-149.

Hidayah, I. 2010. Analisis prioritas komoditas unggulan perkebunan daerah Kabupaten Buru. AGRIKA 4: 1-8. DOI: $10.31328 /$ ja. v4i1.143.
Islamiyah, S.A. 2017. Identifikasi lokasi potensial pengembangan industri pengolahan gula merah lontar di Kabupaten Jeneponto. Perbal: Jurnal Pertanian Berkelanjutan 5: 58-63. DOI: 10.30605/ perbal.v5i1.686

Islamiyah, S.A. 2020. Analisis faktor potensi pengembangan industri pengolahan gula merah lontar di Kabupaten Jeneponto. Journal of Agritech Science 4: 112. DOI: $10.30689 /$ jasc.v4i1.555

Karmiati, K., V.D. Yunianto, dan B.W. Prasetiyono. 2016. Strategi pengembangan agro industri gula tumbu di Kabupaten Kudus. Jurnal Litbang Provinsi Jawa Tengah 14: 25-34. DOI: 10.36762/ jurnaljateng.v14i1.362

Kurniawan, M. dan N. Haryati. 2017. Analisis strategi pengembangan usaha minuman sari buah sirsak. Industria Jurnal Teknologi dan Manajemen Agroindustri 6: 97-102. DOI: 10.21776/ub.industria.2017.006.02.6

Kusumanto, I.H.D. 2016. Analisis peluang pengembangan industri gula aren dalam mendukung pengembangan industri gula aren dalam mendukung swasembada gula nasional. Jurnal Pertanian Tropik 3: 150170. DOI: 10.32734/jpt.v3i2.2970

Maarif, S. dan H. Syam. 2008. Kajian Perlunya Kebijakan Pengembangan Agroindustri Sebagai Leading Sector. Bogor: Program Studi Teknologi Industri Pertanian, Program Doktor PPs IPB Bogor.

Maemunah, S. 2015. Strategi Pengembangan Industri Kecil Gula Aren di Kecamatan Limbangan, Kabupaten Kendal. Skripsi. Jurusan Ekonomi Pembangunan Fakultas Ekonomi Universitas Negeri Semarang. Semarang.

Saputra, E., L. Fitriana, dan E. Bahar. 2012. Strategi pengembangan usaha gula aren di Desa Rambah Tengah Barat Kecamatan Rambah Kabupaten Rokan Hulu. Jurnal Sungkai 1: 22-31. DOI: 10.30606/js.v1i1. 178

Sartina, D.F. 2019. Kemendes PDTT Dorong Pengembangan Produk Unggulan Desa. https://ekonomi.bisnis.com/read/20190621/9 /936322/kemendes-pdtt-dorongpengembangan-produk-unggulan-desa. Diakses: 13 Juli 2020.

Siregar, G., Salman, dan L. Wati. 2014. Strategi pengembangan usaha tahu rumah tangga. 
Agrium 19: 12-20. DOI: 10.30596/agrium. v19i.327

Tambunan, P. 2010. Potensi dan kebijakan pengembangan lontar untuk menambah pendapatan penduduk. Jurnal Analisi Kebijakan Hutan 7: 27-45. DOI: 10.20886/ jakk.2010.7.1.27-45
Rangkuti, F. 2005. Analisis SWOT Teknik Pembedahan Kasus Bisnis. Jakarta: PT. Gramedia Pustaka.

Wongkar, N., J.N.K. Dumais, dan T.M. Katiandagho. 2017. Strategi pengembangan agroindustri gula aren di Desa Tondei 1 . Jurnal Agri-Sosio Ekonomi 13: 215-226. DOI: 10.35791/agrsosek.13.3A.2017.18187 